\title{
The Pinatubo eruption in South Pole snow and its potential value to ice-core paleovolcanic records
}

\author{
Jihong Cole-Dai, ${ }^{1}$ Ellen Mosley-Thompson ${ }^{1,2}$ \\ ${ }^{1}$ Byrd Polar Research Center, The Ohio State University, Columbus, OH 43210, U.S.A. \\ ${ }^{2}$ Department of Geography, The Ohio State University, Columbus, OH 43210, U.S.A.
}

\begin{abstract}
Snow samples collected in the 1996 austral summer at South Pole show that sulfate concentrations in snow and, by inference, sulfur aerosol concentrations in the Antarctic atmosphere were elevated from the end of 1991 to mid-1994 over a stable, nonvolcanic background. The new data support earlier findings that the June 1991 Pinatubo eruption and the Hudson eruption in the same year deposited volcanic sulfate and tephra in South Pole snow, and provide strong evidence of the global distribution of volcanic materials from the Pinatubo eruption. In this study, snow samples were taken in six snow pits spatially distributed around the South Pole station in order to evaluate the local spatial variability of volcanic signals due to glaciological variables such as snow-accumulation rates and snow redistribution by wind after initial deposition. The results indicate that Pinatubo sulfate flux varies by as much as $20 \%$ throughout a $400 \mathrm{~km}^{2}$ area centered around the South Pole station. This glaciological variability probably represents the likely range of volcanic signals due to variations in snow deposition and post-depositional changes.

The Pinatubo eruption provides an unprecedented opportunity to estimate aerosol mass loadings by explosive volcanic eruptions found in Antarctic ice cores via a quantitative relationship between aerosol mass loadings and sulfate flux in Antarctic snow. Here the satellite-estimated Pinatubo $\mathrm{SO}_{2}$ emission and the measured volcanic sulfate flux in snow, with an assumed linearly quantitative relationship, are used to calculate $\mathrm{SO}_{2}$ loadings for several well-known volcanic eruptions in the past 300 years covered by a shallow $(42 \mathrm{~m})$ South Pole firn core drilled in 1996. The errors for the calculated mass loadings are estimated by means of the glaciological variability associated with Pinatubo volcanic flux.
\end{abstract}

\section{INTRODUCTION}

The explosive eruption of the Mount Pinatubo volcano (Luzon, Philippines; $15.14^{\circ} \mathrm{N}, 120.35^{\circ} \mathrm{E}$ ) in June 1991 injected an estimated $18 \pm 2 \times 10^{6}$ metric tons $\left(1 \mathrm{Mt}=1 \mathrm{Tg}=10^{12} \mathrm{~g}\right)$ of $\mathrm{SO}_{2}$ directly into the atmosphere (Krueger and others, 1995). In the atmosphere, the Pinatubo $\mathrm{SO}_{2}$ was rapidly converted to $\mathrm{H}_{2} \mathrm{SO}_{4}$ aerosol particles (Bekki and others, 1993). The volcanic aerosol mass was dispersed gradually in the global atmosphere, covering the entire Earth by mid-1992 (Hitchman and others, 1995). The presence of volcano-derived $\mathrm{H}_{2} \mathrm{SO}_{4} /$ water aerosol particles alters the atmospheric albedo, thereby affecting regional and global climate. Following the Pinatubo eruption, global tropospheric and surface temperatures decreased by $0.2-0.7^{\circ} \mathrm{C}$ (McCormick and others, 1995; Jones and Kelly, 1996).

Aerosol particle fallout and tephra (fine volcanic ash) from explosive volcanic eruptions are found in polar snow. Following a major explosive eruption, sudden increases in the concentrations of $\mathrm{H}_{2} \mathrm{SO}_{4}$ or $\mathrm{SO}_{4}{ }^{2-}$ in polar snow are usually observed during a short period ( $0-3$ years) immediately following the eruption. Consequently, $\mathrm{SO}_{4}{ }^{2-}$ measurements in polar ice cores are used to reconstruct chronological records of global explosive volcanism (Hammer and others, 1980; Legrand and Delmas, 1987; Zielinski and others, 1994, 1996; Cole-Dai and others, 1997a). Pinatubo volcanic signals

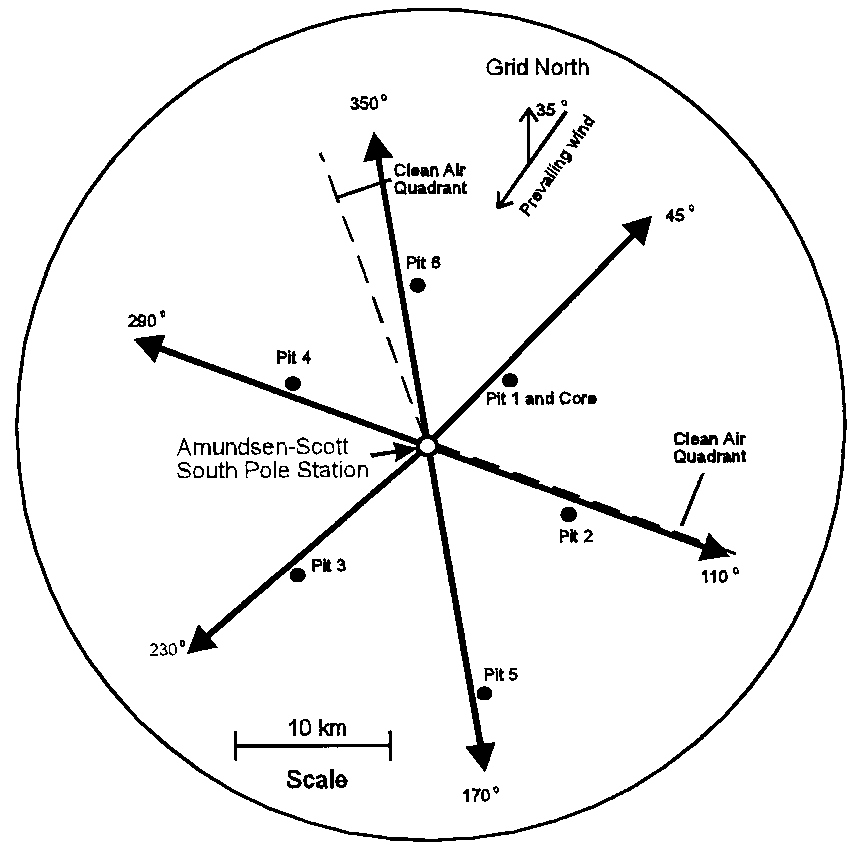

Fig. 1. The Amundsen-Scott South Pole station area: the snow-accumulation network ( solid lines) was established in 1992, and the 1996 snow pits and firn core were located near the survey lines of the network. 


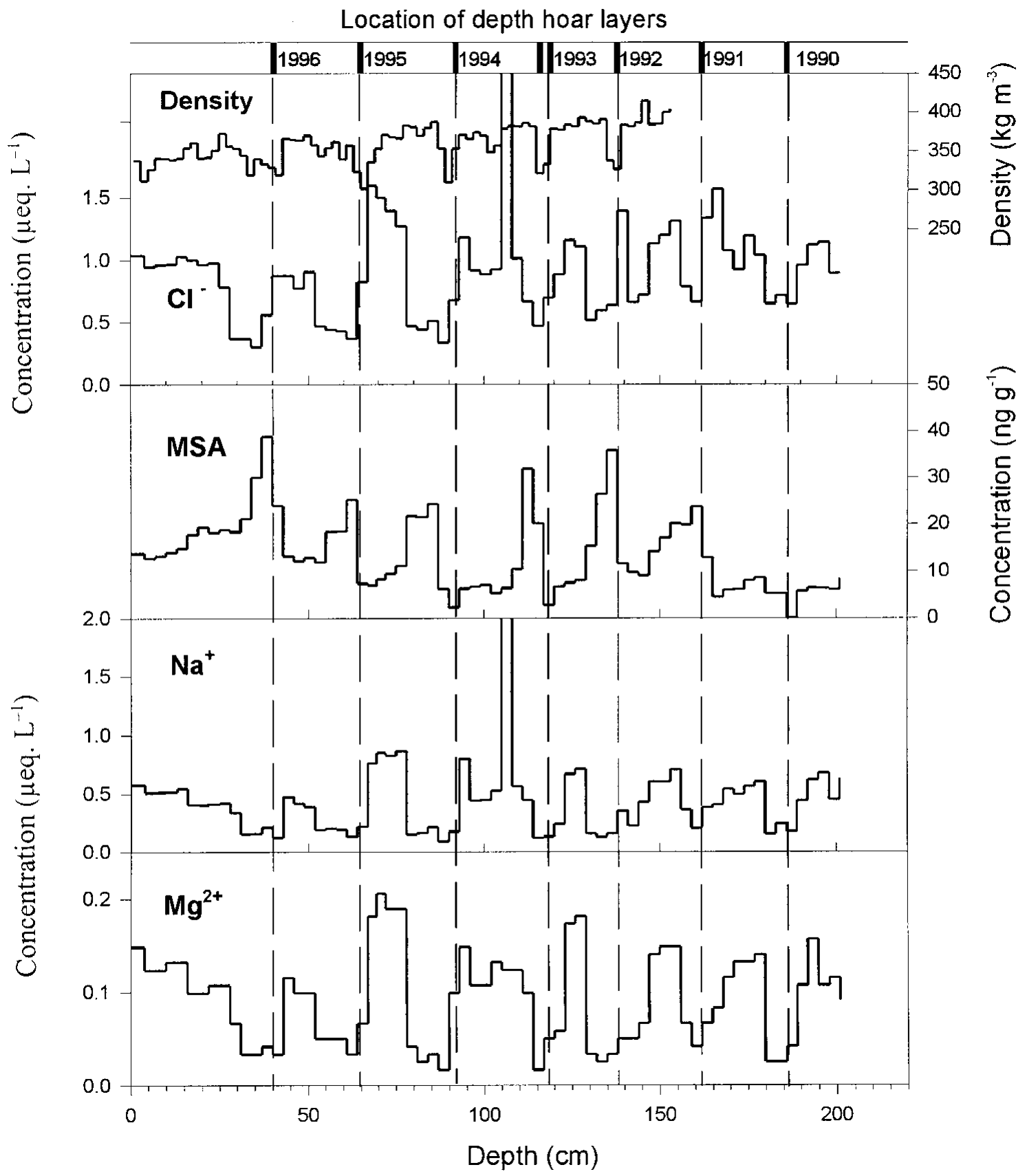

Fig. 2. Density profile and visually identified depth-hoar layers (vertical bars) in pit 6 are shown in the top graph. Concentrations of several ions are plotted on the same depth scale. The dashed vertical lines extending from the depth-hoar layers represent the beginning of the calendar year as marked. Seasonal cycles in $\mathrm{Cl}, \mathrm{MSA}, \mathrm{Na}^{+}$and $\mathrm{Mg}^{2+}$ concentrations are identified based on comparison with the annual depth-hoar layers.

were recently found in South Pole snow (Dibb and Whitlow, 1996; Cole-Dai and others, 1997b). In a previous study (ColeDai and others, 1997b), the volcanic $\mathrm{SO}_{4}{ }^{2-}$ flux in two 1994 shallow South Pole cores was quantified. In this study we seek to verify the previous results with South Pole snow samples collected in 1996 and, more importantly, to evaluate the local spatial variability of the Pinatubo signal as preserved in South Pole snow. Along with samples from multiple snow pits around the Amundsen-Scott South Pole station, a 42 m firn core was recovered during the 1996 field season. This core is used to detect and quantify volcanic signals of major volcanic eruptions during the past 300 years, and to estimate total atmospheric aerosol loadings (in $\mathrm{SO}_{2}$ ) from these eruptions. These estimates can be used to assess the magnitude of volcanic forcing on climate, as the climatic impact is closely related to the amount of climatologically active volcanic aerosols generated by volcanic eruptions (Minnis and others, 1993; Zielinski, 1995).

\section{SNOW SAMPLING, ICE GORING AND ANALYSIS}

A shallow core (42 m) was drilled and several snow pits were sampled during November and December 1996 at the South Pole station. The firn core was recovered with an electromechanical drill at a location $6 \mathrm{~km}$ upwind $\left(\right.$ grid $045^{\circ}$ ) from the station (Fig. 1). Snow pits to $2 \mathrm{~m}$ were excavated along the lines of an accumulation network (Fig. 1) established in 1992 to measure annual snowfall (Mosley-Thompson and others, 1995). A total of six pits were excavated and sampled. The 
following observations were made and snow sampling was conducted in each pit: (1) thin (a few $\mathrm{cm}$ ) horizontal snow layers characterized by large snow grains and low density were visually identified and their depths were recorded; (2) beginning at the pit bottom, a vertically continuous sequence of $3 \mathrm{~cm}$ snow samples was collected using the following procedure: the sample collector wore a face mask and vinyl gloves and used stainless-steel spatulas to chisel samples from pit walls and to transfer samples to $120 \mathrm{~mL}$ polypropylene specimen cups (all gloves, tools and sample containers had been pre-cleaned and tested to prevent contamination); (3) in four of the six pits, a second set of samples was taken in parallel to the first set with a fixed-volume sampler for density measurements.

Snow-pit samples in specimen containers and the firn core were transported frozen to the Byrd Polar Research Center (BPRG) at The Ohio State University and were stored in a $-30^{\circ} \mathrm{C}$ freezer until laboratory analysis. Individual samples averaging $2.5 \mathrm{~cm}$ in length were prepared from the firn core under stringent contamination control. All samples were melted at room temperature and analyzed by ion chromatography (IC) in the BPRC ice-core laboratory for concentrations of common inorganic ions $\left(\mathrm{Na}^{+}, \mathrm{K}^{+}, \mathrm{Mg}^{2+}, \mathrm{Ca}^{2+}, \mathrm{Cl}^{-}\right.$, $\left.\mathrm{NO}_{3}{ }^{-}, \mathrm{SO}_{4}{ }^{2-}\right)$. Detailed procedures for ice-core sample preparation and IC analysis are described elsewhere (Dai and others, 1995). The concentrations of methanesulfonic acid or MSA $\left(\mathrm{CH}_{3} \mathrm{CHSO}_{3} \mathrm{H}\right)$ in selected samples were determined with gradient IC according to published IC methods (Saigne and others, 1987).

\section{RESULTS}

All $\mathrm{SO}_{4}{ }^{2-}$ data reported in this work are non-sea-salt (nss) $\mathrm{SO}_{4}{ }^{2-}$, calculated from the total $\mathrm{SO}_{4}{ }^{2-}$ and $\mathrm{Na}^{+}$concentrations in each sample. Data from an earlier study (Cole-Dai and others, 1997b) and this work indicate that there is relatively little sea-salt-derived $\mathrm{SO}_{4}{ }^{2-}$ in South Pole snow, with $\mathrm{nssSO}_{4}{ }^{2-}$ representing $>95 \%$ of the total $\mathrm{SO}_{4}{ }^{2-}$ concentration.

\section{Snow-layer chronology}

Previous studies (Legrand and Delmas, 1984; Whitlow and others, 1992) have found that concentrations of several ionic species in South Pole snow exhibit seasonal oscillations which can be used to date snow layers as a function of depth. During pit sampling, intermittent thin layers with large snow grains were observed in snow-pit stratigraphy. The gradual increase in snow density with depth is punctuated by these low-density thin layers (Fig. 2, top graph). These layers fit the definition of depth-hoar layers, first identified by Gow (1965), which appear annually in early summer snow. Dates are assigned to the annual depth-hoar layers at the beginning of the calendar year (top of Fig. 2). Matching these markers of summer snow (dashed lines in Fig. 2) with the concentration profiles of ionic species reveals that several species follow seasonal cycles. As seen in Figure 2, the concentrations of $\mathrm{Na}^{+}, \mathrm{Cl}^{-}$and $\mathrm{Mg}^{2+}$ are relatively high in winter snow and low in summer, while MSA concentrations generally reach a maximum during summer. These visible markers and seasonal concentration cycles, in agreement with observations by Legrand and Delmas (1984) and by Whitlow and others (1992), provide excellent tools for dating snow layers at South Pole.

To convert snow-pit depth into water-equivalent (w.e.) depth, the density of each sample is needed. A second-order polynomial was fitted to the density-depth profile for pit 6 (Fig. 2, top graph) and was then used to calculate the density of each of the samples in all six snow pits. Annual snowaccumulation rates for the $6-8$ years contained in the snow pits are obtained (Table 1) using the annual layer markers and seasonal cycles. The spatially and temporally averaged annual accumulation rate from 1990 to 1996 calculated from the six snow pits is $94 \mathrm{~mm}$ w.e. $\mathrm{a}^{-1}\left(251 \mathrm{~mm}\right.$ snow $\left.\mathrm{a}^{-1}\right)$. This is slightly higher than, but not inconsistent with, the annual average of $84.5 \mathrm{~mm}$ w.e. from 1992 to 1996 based on the 236-pole accumulation network (Mosley-Thompson and others, 1999). Data shown in Table 1 suggest that the interannual variability can be high at a single pit site (relative standard deviation (RSD) as large as $40 \%$ ). However, the

Table 1. Summary of results of the 1996 South Pole snow-pit study

\begin{tabular}{|c|c|c|c|c|c|c|c|}
\hline & Pit 1 & Pit 2 & Pit 3 & Pit 4 & Pit 5 & Pit 6 & Average \\
\hline Grid location (see Fig. 1) & $045^{\circ}$ & $110^{\circ}$ & $230^{\circ}$ & $290^{\circ}$ & $170^{\circ}$ & $50^{\circ}$ & \\
\hline Number of whole years in pit & 6 & 7 & 7 & 7 & 8 & 7 & \\
\hline $\begin{array}{l}\text { Mean annual accumulation }\left(\mathrm{mm} \mathrm{snow}^{-1}\right) \\
\text { RSD }(\%) \\
\text { Mean annual accumulation }\left(\mathrm{mm} \text { w.e. } \mathrm{a}^{-1}\right) \\
\text { RSD }(\%)\end{array}$ & $\begin{array}{l}293 \\
(25) \\
107 \\
(24)\end{array}$ & $\begin{array}{c}239 \\
(18) \\
90 \\
(18)\end{array}$ & $\begin{array}{c}224 \\
(12) \\
85 \\
(14)\end{array}$ & $\begin{array}{c}259 \\
(27) \\
98 \\
(28)\end{array}$ & $\begin{array}{c}230 \\
(18) \\
88 \\
(48)\end{array}$ & $\begin{array}{c}260 \\
(17) \\
97 \\
(10)\end{array}$ & $\begin{array}{c}251 \\
(9.2) \\
94 \\
(7.9)\end{array}$ \\
\hline $\begin{array}{l}\text { Non-volcanic } \mathrm{SO}_{4}{ }^{2-}\left(\mu \mathrm{eq} \mathrm{L}^{-1}\right) \\
\quad \text { (std dev.) }\end{array}$ & 1.06 & 1.17 & 0.94 & 1.00 & 1.00 & 1.03 & $\begin{array}{c}1.03 \\
(0.07)\end{array}$ \\
\hline $\begin{array}{l}\text { Pinatubo } \mathrm{SO}_{4}{ }^{2-} \text { flux }\left(\mathrm{kg} \mathrm{m}^{-2}\right) \\
\text { (std dev.) }\end{array}$ & 9.47 & 9.82 & 7.89 & 6.94 & 6.34 & 9.74 & $\begin{array}{l}8.37 \\
(1.39)\end{array}$ \\
\hline $\begin{array}{l}\text { Hudson } \mathrm{SO}_{4}{ }^{2-} \text { flux }\left(\mathrm{kg} \mathrm{km}^{-2}\right) \\
\text { (std dev.) }\end{array}$ & 2.75 & 3.79 & 3.65 & 5.24 & 1.87 & 4.28 & $\begin{array}{l}3.60 \\
(1.07)\end{array}$ \\
\hline
\end{tabular}

Notes: Pit depths ranged from 1.8 to $2.1 \mathrm{~m}$. Annual snow accumulation was obtained using annual markers and converted to water-equivalent accumulation based on a modeled density curve (see text for details). The Pinatubo volcanic sulfate deposition lasts 2.5 years and the Hudson deposition is $\sim 1$ year. 


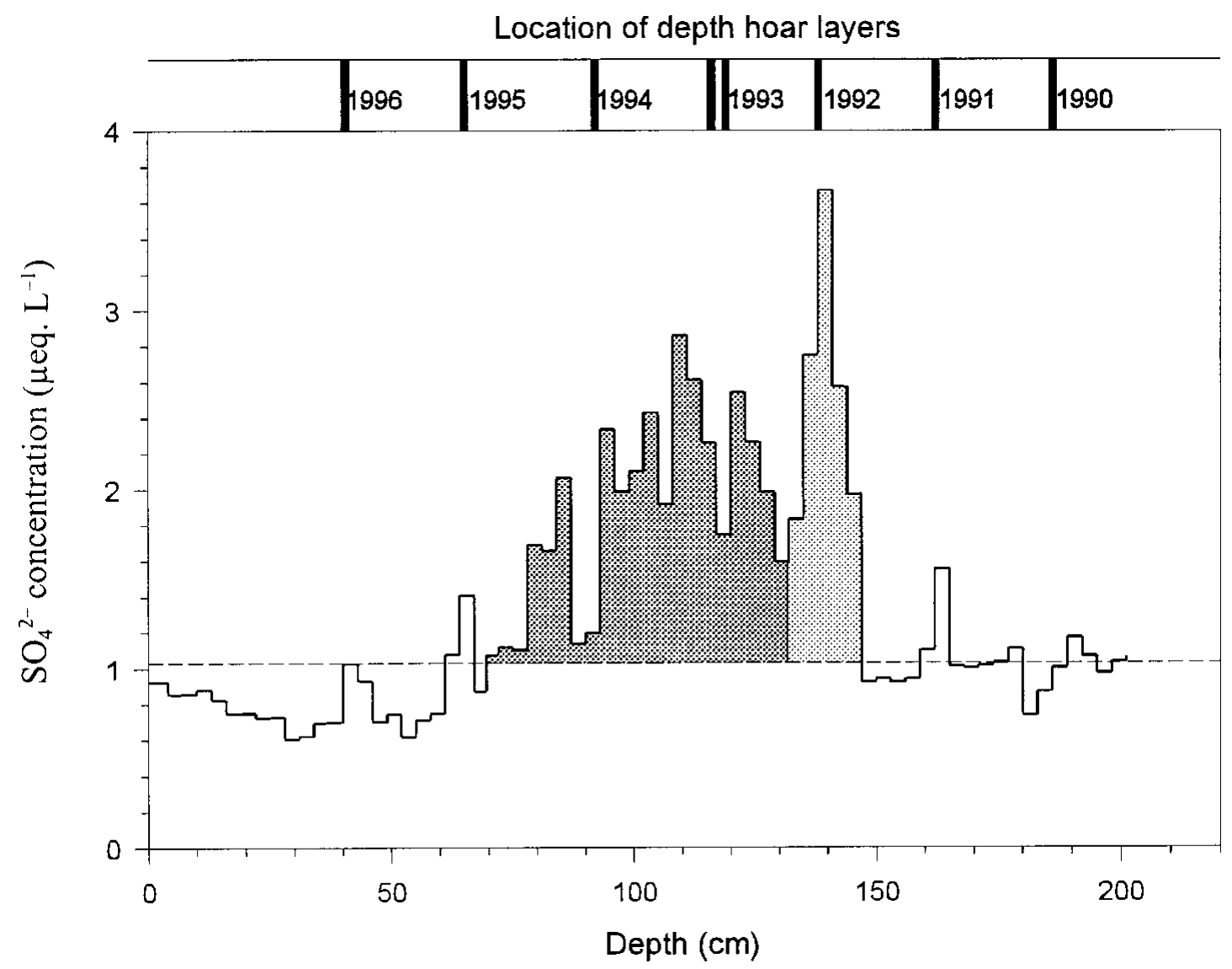

Fig. 3. Concentration of $\mathrm{SO}_{4}{ }^{2-}$ in South Pole pit 6 is shown as a function of depth. Horizontal dashed line represents the non-volcanic background concentration. Increased $\mathrm{SO}_{4}^{2-}$ concentrations (shaded area) above the background represent volcanic fallout from Pinatubo (dark shading) from early or mid-1992 to mid-1994 and Hudson (light shading) from late 1991 to early or mid-1992.

spatial variability across the study area is relatively small (RSD $\sim 7 \%$ ) after the accumulation rates from each pit are temporally averaged.

\section{The Hudson eruption}

The August 1991 eruption of Cerro Hudson, southern Chile $\left(45.92^{\circ} \mathrm{S}, 73.00^{\circ} \mathrm{W}\right)$, injected an estimated $1.5 \mathrm{MtSO}_{2}$ into the atmosphere (Doiron and others, 1991). Deposition of Hudson-derived $\mathrm{SO}_{4}{ }^{2-}$ in Antarctic snow is significant due to the relative proximity of Cerro Hudson to Antarctica and the rapid transport of its aerosols into the high southern latitudes (Doiron and others, 1991). Lidar observations over Antarctica (Deshler and others, 1992; Cacciani and others, 1993) indicate that Hudson aerosols entered the polar atmosphere at the upper-troposphere/lower-stratosphere altitudes beneath the polar vortex in September and October 1991, prior to the arrival of the Pinatubo aerosol mass at higher altitudes. Dibb and Whitlow (1996) and Cole-Dai and others (1997b) found apparent volcanic events in recent South Pole snow. Cole-Dai and others (1997b) determined that two volcanic events were present in 1992-94 snow layers and that the earlier event is probably Hudson. In Figure 3 two volcanic events in a 1996 snow pit (pit 6) are shown at depths corresponding to 1992-94. Two similar events are found in all other 1996 snow pits. Following the conclusions by Cole-Dai and others (1997b), the more recent event is assumed to be Pinatubo, and the earlier one to be Hudson. The snow-layer chronology suggests that Hudson aerosol deposition lasted from late 1991 to early or mid-1992 $(<1$ year) and Pinatubo deposition covered the period from early or mid-1992 to mid-1994 ( $\sim 2.5$ years $)$.

\section{Calculation of background sulfate concentrations and volcanic flux}

Non-volcanic or background $\mathrm{SO}_{4}{ }^{2-}$ in Antarctic snow is derived mainly from marine biogenic emissions of organic sulfur compounds dominated by dimethylsulfide or DMS (Legrand, 1995; Legrand and Mayewski, 1997). It has been assumed that temporal variations of background $\mathrm{SO}_{4}{ }^{2-}$ concentrations in Antarctic snow are not systematically influenced by DMS emission rates from marine sources or by transport and depositional processes (Cole-Dai and others, 1997a). Therefore, the typical background $\mathrm{SO}_{4}{ }^{2-}$ concentrations may be approximated using mean $\mathrm{SO}_{4}{ }^{2-}$ concentrations for an extended period free of significant volcanic input. Snow layers of 1-2 years prior to 1991 in the pits were deposited during a period of global volcanic quiescence (Hitchman and others, 1995). Consequently, in each pit the mean $\mathrm{SO}_{4}{ }^{2-}$ concentration below the 1991 snow layer is assumed to represent the non-volcanic or background $\mathrm{SO}_{4}{ }^{2-}$ concentration (Table 1). For the firn core, a background $\mathrm{SO}_{4}{ }^{2-}$ concentration of $1.12 \mu \mathrm{eq} \mathrm{L}{ }^{-1}$ (std dev. $0.26 \mu \mathrm{eq} \mathrm{L}^{-1}$ ) is calculated by averaging $\mathrm{SO}_{4}{ }^{2-}$ concentration over the length of the core, after excluding samples associated with apparent volcanic events. Delmas and others (1992) reported a very similar background 


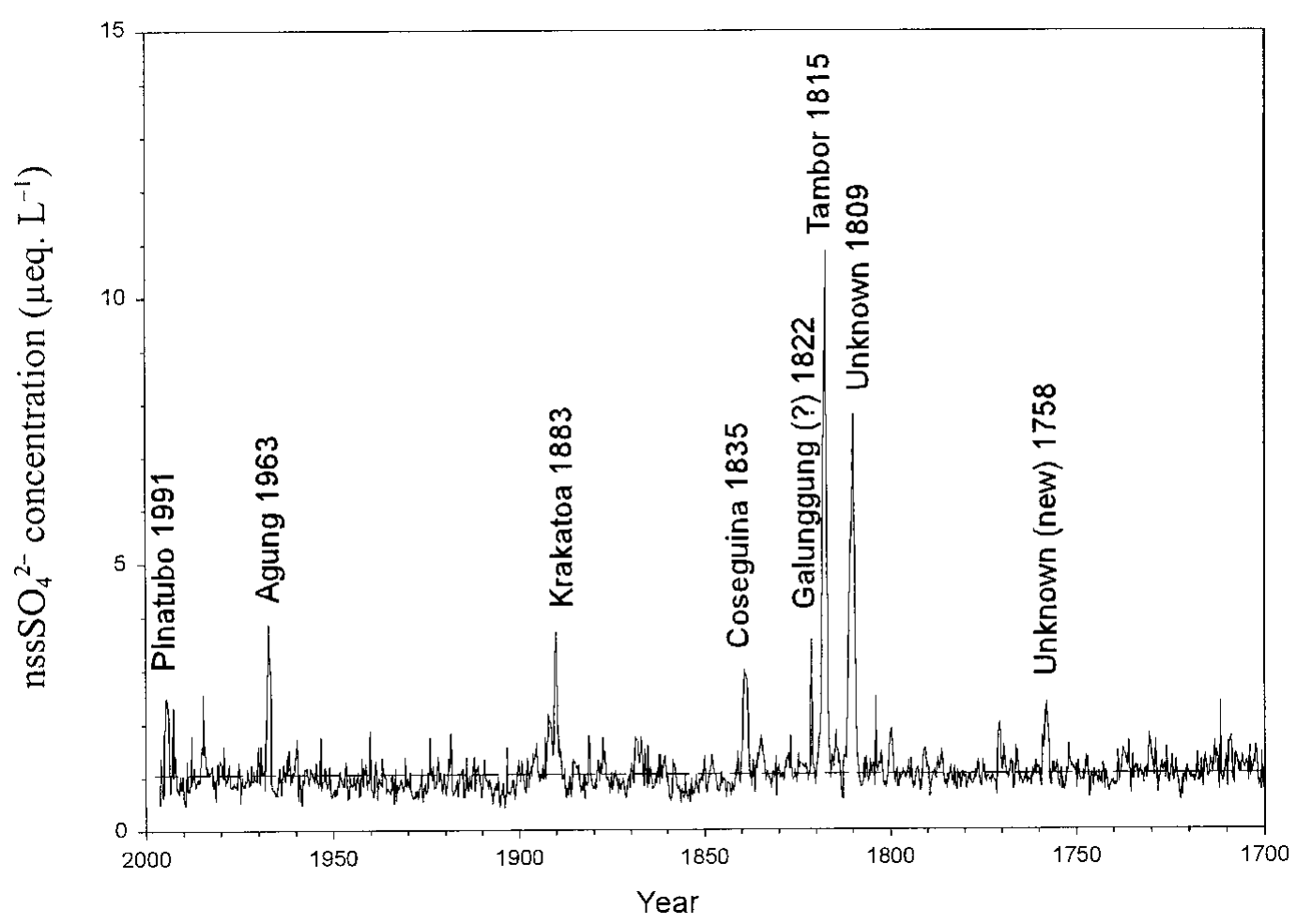

Fig. 4. The continuous $\mathrm{SO}_{4}{ }^{2-}$ concentration profile for the entire $42 \mathrm{~m}$ core is presented on a time-scale. Dating of the $42 \mathrm{~m}$ firn core is accomplished by an average annual accumulation rate obtained from the identification of the 1815 Tambora eruption (see text for details). Outstanding volcanic events as marked with eruption dates are identified according to the years of their appearance in the core.

$\mathrm{SO}_{4}{ }^{2-}$ concentration of $1.14 \pm 0.24 \mu \mathrm{eq} \mathrm{L}^{-1}\left(55.0 \pm 11.6 \mathrm{ng} \mathrm{g}^{-1}\right)$ in an earlier South Pole core.

Volcanic $\mathrm{SO}_{4}{ }^{2-}$ flux in an individual sample is calculated by first subtracting background $\mathrm{SO}_{4}{ }^{2-}$ from the sample $\mathrm{SO}_{4}{ }^{2-}$ concentration and then multiplying by the sample length in water equivalent. Total volcanic flux for a volcanic event is simply the sum of the volcanic flux of all samples associated with that event. The volcanic fluxes of Hudson ( $\leq 1$ year) and Pinatubo ( $\sim 2.5$ years $)$ for all six pits are listed in Table 1 .

\section{Dating of the firn core}

A time-scale is required for the $42 \mathrm{~m}$ core to estimate the ages of several prominent volcanic events found in the core. As all annual layers in the core have yet to be identified, the core dating can only be accomplished by assuming a constant accumulation rate. Mosley-Thompson and others (1999) reported a substantial increase $(\geq 30 \%)$ in snow-accumulation rates at South Pole during the past 40 years. Thus, the average accumulation rate of $94 \mathrm{~mm}$ w.e. $\mathrm{a}^{-1}$ obtained from the snow pits is not accurate for snow layers older than 40 years and may result in large dating errors for deeper parts of the core. Fortunately, two prominent volcanic events were found at 27.6 and $28.6 \mathrm{~m}$ in the core and are recognized as the Tambora eruption in 1815 and the eruption in 1809 of unknown origin, respectively, which are well documented in previous works (Legrand and Delmas, 1987; Dai and others, 1991; Delmas and others, 1992). The depths of these events in the $42 \mathrm{~m}$ core are consistent with those in a core drilled at South Pole in 1984 (Delmas and others, 1992), after accounting for the 12 year additional accumulation. Using these two time markers, the average accumulation rate of $77.0 \mathrm{~mm}$ w.e. $\mathrm{a}^{-1}$ is obtained for $1810-1996$. This accumulation rate is then used for the entire core, and the age at the bottom of the $42 \mathrm{~m}$ core is approximately 300 years ( $\sim \mathrm{AD} 1698)$.

\section{DISGUSSION}

\section{Local spatial variability of Pinatubo flux at South Pole}

The six 1996 snow pits encompass an estimated $400 \mathrm{~km}^{2}$ area around the South Pole station (see Fig. 1). Data in Table 1 show that within this area the Pinatubo $\mathrm{SO}_{4}{ }^{2-}$ flux $\left(8.37 \pm 1.46 \mathrm{~kg} \mathrm{~km}^{-2}\right.$ at the $95 \%$ confidence level) contains a maximum uncertainty of about $20 \%$. This uncertainty can be attributed mainly to the large spatial and temporal variability of annual snow-accumulation rate at South Pole (Mosley-Thompson and others, 1995, 1999). Primary factors responsible for the large accumulation variability include surface topographic irregularities and snow redistribution by wind after deposition. Another contributing factor is the large variability in the density of surface and shallow snow layers. Since flux calculations are dependent on density, large density variations can result in significant errors in flux calculation. Accurate flux calculation would require that the density of each sample be measured individually so that its volume can be converted to water equivalent using its own density. This was not possible in this study as density measurements are difficult for very small samples.

This uncertainty of volcanic flux due to local glaciological factors and inherent errors in measurements on snow samples may be termed glaciological variability. The errors in estimating volcanic aerosol mass loadings using ice-core data are dependent on the glaciological variability, among many factors.

\section{Previous volcanic eruptions and estimating aerosol mass loadings}

Continuous $\mathrm{SO}_{4}{ }^{2-}$ concentrations for the $42 \mathrm{~m}$ core are shown in Figure 4 as a function of time. Several outstanding 
volcanic $\mathrm{SO}_{4}{ }^{2-}$ events are found in the core (Table 2). Most have been identified previously in Antarctic ice cores (Delmas and others, 1992; Cole-Dai and others, 1997a). The exception is the signal dated at approximately 1758 , to be investigated in future work in order to identify the responsible volcanic eruption.

The volcanic flux for each of the events is calculated and listed in Table 2. The estimated volcanic flux for the 1815 Tambora eruption in this work $\left(47 \mathrm{~kg} \mathrm{~km}^{-2}\right)$ is similar to that $\left(43 \mathrm{~kg} \mathrm{~km}^{-2}\right)$ reported by Legrand and Delmas (1987) in a 1978 core, but less than that $\left(67 \mathrm{~kg} \mathrm{~km}^{-2}\right)$ from a 1984 South Pole core (Delmas and others, 1992). The difference appears to be larger than expected from the local spatial variability or glaciological variability of about $17 \%$ as estimated in this work (Table 1). The ratio of the volcanic flux of the unknown 1809 eruption to that of Tambora (0.80) is also larger than those reported for other Antarctic ice cores (e.g. 0.40 and 0.60 in two Antarctic Peninsula cores; see Cole-Dai and others, 1997a), probably as a result of the low Tambora flux estimate from this $42 \mathrm{~m}$ core. This apparent discrepancy warrants further investigation in future research.

Table 2. Prominent volcanic events found in the 1996 South Pole core (Fig. 4)

\begin{tabular}{lccccc}
\hline Eruption & Yearin & Duration & Volcanicflux & $f / f_{\text {Pinatubo }}$ & $\begin{array}{c}\text { Estimated } \\
M\end{array}$ \\
& & & & & \\
& & years & $\mathrm{kg} \mathrm{km}^{-2}$ & & $\mathrm{Mt}$ \\
& & & & & \\
\hline Pinatubo 1991 & 1993 & 2.5 & 8.37 & 1.00 & $18 \pm 2^{*}$ \\
Agung 1963 & 1966 & 1.3 & 9.63 & 1.15 & $20.7 \pm 3.5$ \\
Krakatoa 1883 & 1888 & 1.1 & 8.18 & 0.98 & $17.6 \pm 3.0$ \\
Coseguina 1835 & 1838 & 1.5 & 9.28 & 1.11 & $20.0 \pm 3.4$ \\
Galunggung (?) & 1821 & 0.5 & 2.38 & 0.28 & $5.1 \pm 0.9$ \\
$\quad(1822)$ & & & & & \\
Tambora 1815 & 1817 & 3.0 & 44.2 & 5.28 & $95.0 \pm 16$ \\
Unknown 1809 & 1811 & 2.9 & 35.5 & 4.24 & $76.3 \pm 13$ \\
? (new, unknown) & 1758 & 1.9 & 6.02 & 0.72 & $12.9 \pm 2.2$ \\
& & & & &
\end{tabular}

Notes: Volcanic sulfate flux $(f)$ for each event is calculated using the method described in this work. Estimated aerosol mass loadings or $\mathrm{SO}_{2}$ emissions $(M)$ for previous volcanic events (column 6) are calculated according to Equation (1). The ranges $( \pm)$ of the estimates are calculated from the glaciological variability $(17 \%)$ of Pinatubo volcanic flux as derived from the pit study.

* Total $\mathrm{SO}_{2}$ emission measured in situ by space-borne instruments (Krueger and others, 1995).

The volcanic flux of an eruption in polar snow is related to the atmospheric aerosol mass loading (in tons of $\mathrm{SO}_{2}$ or $\mathrm{H}_{2} \mathrm{SO}_{4}$ ) by that eruption. Several earlier studies (Hammer and others, 1980; Delmas and others, 1985; Legrand and Delmas, 1987) have attempted to estimate aerosol mass loadings from older volcanic eruptions found in ice cores by using debris fallout from atmospheric nuclear explosions. However, no error ranges were provided for estimates of aerosol mass loadings obtained this way.

Since its aerosol mass loading $\left(18 \pm 2 \mathrm{Mt} \mathrm{SO}_{2}\right)$ has been determined in situ by satellite instruments, the Pinatubo eruption may be used as a calibrating tool for similar aerosol-loading estimates. This may be advantageous over the use of the nuclear-bomb fallout, for the atmospheric transport and deposition in snow of bomb debris are likely to be different from those of volcanic aerosols. To estimate aerosol mass loadings and the corresponding uncertainty, three important factors must be considered concerning the quantitative relationship between aerosol loadings and volcanic deposit in polar snow: (1) the efficiency of aerosol transport from the location of the volcano to the polar atmosphere; (2) the efficiency of aerosol deposition and/or scavenging by snow; and (3) the glaciological variability of the signal as defined earlier. The first two factors, although critical, are beyond the scope of this work, and therefore the same efficiency in aerosol transport and deposition for all events including Pinatubo is assumed for the following calculations. The assumption may not be valid since the atmospheric processes are poorly understood at this point. Errors due to these processes may be significant but are not included for the aerosol estimates in this study.

The aerosol mass loading ( as $\mathrm{SO}_{2}$ ) from an earlier volcanic event can be estimated by

$$
M_{\mathrm{i}}=R_{\mathrm{i}} M_{\mathrm{p}}=\left(f_{\mathrm{i}} / f_{\mathrm{p}}\right) M_{\mathrm{p}},
$$

where $M_{\mathrm{p}}$ and $f_{\mathrm{p}}$ are the total $\mathrm{SO}_{2}$ emission and volcanic $\mathrm{SO}_{4}{ }^{2-}$ flux for Pinatubo, respectively, and $f_{\mathrm{i}}$ is the volcanic $\mathrm{SO}_{4}{ }^{2-}$ flux for the event. Results listed in Table 2 show that the 1815 Tambora eruption injected approximately $95 \mathrm{Mt}$ $\mathrm{SO}_{2}$ into the atmosphere. Earlier estimates for Tambora range from 120 to $170 \mathrm{MtSO}_{2}$ using ice cores from several Greenland locations (Clausen and Hammer, 1988). In Antarctica, the estimates range from 98 to $238 \mathrm{Mt}$ (Legrand and Delmas, 1987; Langway and others, 1988; Delmas and others, 1992). None of the earlier studies provided an assessment of local spatial variability of the Tambora signal, which makes it difficult to compare these results. However, the estimate from this 1996 core is remarkably similar to that ( 100 Mt) obtained by Legrand and Delmas (1987) who used a different calibration method.

\section{GONGLUSIONS}

Sulfate deposits from the Pinatubo eruption are found in recently (1996) collected South Pole snow samples. The new data confirm earlier findings and support the conclusion that Pinatubo $\mathrm{SO}_{4}{ }^{2-}$ deposition lasted from early or mid1992 to mid-1994, preceded by a short deposition period (late 1991 to early or mid-1992) of volcanic aerosols from the Hudson eruption. Calculations show that the Pinatubo volcanic flux is similar to that of the 1963 Agung (Bali, Indonesia) eruption.

The deposition of Pinatubo volcanic $\mathrm{SO}_{4}{ }^{2-}$ appears to be locally consistent in the South Pole area, as volcanic signals are found in six snow pits distributed across a $400 \mathrm{~km}^{2}$ area. Results of the pit study indicate that spatial variability in Pinatubo $\mathrm{SO}_{4}{ }^{2-}$ flux may be as large as $20 \%$ at South Pole, probably due to spatial variations in annual net snow accumulation.

The Pinatubo eruption and many explosive volcanic eruptions during the past 300 years are also found in a shallow firn core. The atmospheric aerosol loadings by these past eruptions are estimated assuming atmospheric transport and deposition efficiencies similar to those of Pinatubo. In addition to the volcanic events reported in previous Antarctic ice cores, a new event is found around AD 1758. This event requires verification in other cores, and, if verified, the volcanic eruption responsible for this signal needs to be identified in future research. 


\section{ACKNOWLEDGEMENTS}

We wish to thank the Polar Ice Coring Office, Fairbanks, Alaska, for drilling the firn core at South Pole, and R. Hellstrom for assistance with the fieldwork. We are grateful to two anonymous reviewers for their comments that helped improve the manuscript. This work is supported by U.S. National Science Foundation grant OPP-9526725 to The Ohio State University. This is contribution No. 1107 of the Byrd Polar Research Center.

\section{REFERENCES}

Bekki, S., R. Toumi and J. A. Pyle. 1993. Role of sulfur photochemistry in tropical ozone changes after the eruption of Mount Pinatubo. Nature, 362 (6418), 331-333.

Cacciani, M., P. di Girolamo, A. di Sarra, G. Fiocco and D. Fua. 1993. Volcanic aerosol layers observed by lidar at South Pole, September 1991-June 1992. Geophys. Res. Lett., 20(9), 807-810.

Clausen, H. B. and C. U. Hammer. 1988. The Laki and Tambora eruptions as revealed in Greenland ice cores from 11 locations. Ann. Glaciol., 10, 16-22.

Cole-Dai, J., E. Mosley-Thompson and L. G. Thompson. 1997a. Annually resolved Southern Hemisphere volcanic history from two Antarctic ice cores. 7. Geophys. Res., 102(D14), 16,761-16,771.

Cole-Dai, J., E. Mosley-Thompson and L. G. Thompson. 1997b. Quantifying the Pinatubo volcanic signal in south polar snow. Geophys. Res. Lett., 24(21), 2679-2682.

Dai, J., E. Mosley-Thompson and L. G. Thompson. 1991. Ice core evidence for an explosive tropical volcanic eruption 6 years preceding Tambora. 7. Geophys. Res., 96 (D9), 17,361-17,366.

Dai, J. G., L. G. Thompson and E. Mosley-Thompson. 1995. A 485 year record of atmospheric chloride, nitrate and sulfate: results of chemical analysis of ice cores from Dyer Plateau, Antarctic Peninsula. Ann. Glaciol., 21, 182-188.

Delmas, R. J., M. Legrand, A. J. Aristarain and F. Zanolini. 1985. Volcanic deposits in Antarctic snow and ice. 7. Geophys. Res., 90 (D7), 12,901-12,920.

Delmas, R. J., S. Kirchner, J. M. Palais and J.-R. Petit. 1992. 1000 years of explosive volcanism recorded at the South Pole. Tellus, 44B (4), 335-350.

Deshler, T., A. Adriani, G. P. Gobbi, D. J. Hofmann, G. di Donfrancesco and B. J. Johnson. 1992. Volcanic aerosol and ozone depletion within the Antarctic polar vortex during the austral spring of 1991. Geophys. Res. Lett., 19(18), 1819-1822.

Dibb, J. E. and S. Whitlow. 1996. Recent climatic anomalies and their impact on snow chemistry at South Pole, 1987-1994. Geophys. Res. Lett., 23(10), 1115-1118.

Doiron, S. D., G. J.S. Bluth, C. C. Schnetzler, A. J. Krueger and L. S. Walter. 1991. Transport of Cerro Hudson SO 2 clouds. EOS, 72 (45), 489.

Gow, A. J. 1965. On the accumulation and seasonal stratification of snow at the South Pole. 7. Glaciol., 5(40), 467-477.

Hammer, C. U., H. B. Clausen and W. Dansgaard. 1980. Greenland ice sheet evidence of post-glacial volcanism and its climatic impact. Nature, 288(5788), 230-235.

Hitchman, M. H., M. McKay and C. R. Trepte. 1995. A climatology of stratospheric aerosol. 7. Geophys. Res., 99 (D10), 20,698-20,700.

Jones, P. D. and P. M. Kelly. 1996. The effect of tropical explosive volcanic eruptions on surface air temperature. In Fiocco, G., D. Fu'a and G. Visconti, eds. The Pinatubo eruption: effects on the atmosphere and climate. Berlin, etc., Springer-Verlag, 95-112. (NATO ASI Series I: Global Environmental Change 42.)

Krueger, A. J. and 6 others. 1995. Volcanic sulfur dioxide measurements from the total ozone mapping spectrometer instruments. 7. Geophys. Res., 100 (D7), 14,057-14,076.

Langway, C. C., Jr, H. B. Clausen and C. U. Hammer. 1988. An inter-hemispheric volcanic time-marker in ice cores from Greenland and Antarctica. Ann. Glaciol., 10, 102-108.

Legrand, M. 1995. Sulphur-derived species in polar ice: a review. In Delmas, R. J., ed. Ice core studies of global biogeochemical cycles. Berlin, etc., SpringerVerlag, 91-119. (NATO ASI Series I: Global Environmental Change 30.)

Legrand, M. R. and R. J. Delmas. 1984. The ionic balance of Antarctic snow: a 10 year detailed record. Atmos. Environ., 18(9), 1867-1874.

Legrand, M. R. and R. J. Delmas. 1987. A 220-year continuous record of volcanic $\mathrm{H}_{2} \mathrm{SO}_{4}$ in the Antarctic ice sheet. Nature, 327(6124), 671-676.

Legrand, M. and P. Mayewski. 1997. Glaciochemistry of polar ice cores: a review. Rev. Geophys., 35(3), 219-243.

McCormick, M. P., L.W. Thompson and C. R. Trepte. 1995. Atmospheric effects of the Pinatubo eruption. Nature, 373(6513), 399-403.

Minnis, P. and 6 others. 1993. Radiative climate forcing by the Mount Pinatubo eruption. Science, 259(5100), 1411-1415.

Mosley-Thompson, E. and 6 others. 1995. Recent increase in South Pole snow accumulation. Ann. Glaciol., 21,131-138.

Mosley-Thompson, E., J. F. Paskievitch, A. J. Gow and L. G. Thompson. 1999. Late 20th century increase in South Pole snow accumulation. $\mathcal{F}$. Geophys. Res., 104(D4), 3877-3886.

Saigne, G., S. Kirchner and M. Legrand. 1987. Ion-chromatographic measurements of ammonium, fluoride, acetate, formate, and methanesulphonate ions at very low levels in Antarctic ice. Anal. Chim. Acta, 203(1), 11-21.

Whitlow, S., P. A. Mayewski and J. E. Dibb. 1992. A comparison of major chemical species seasonal concentration and accumulation at the South Pole and Summit, Greenland. Atmos. Environ., 26A(11), 2045-2054.

Zielinski, G. A. 1995. Stratospheric loading and optical depth estimates of explosive volcanism over the last 2100 years derived from the Greenland Ice Sheet Project 2 ice core. 7. Geophys. Res., 100(D10), 20,937-20,955.

Zielinski, G. A. and 8 others. 1994. Record of volcanism since 7000 B.C. from the GISP2 Greenland ice core and implications for the volcano-climate system. Science, 264(5161), 948-952.

Zielinski, G. A., P. A. Mayewski, L. D. Meeker, S. I. Whitlow and M. S. Twickler. 1996. 110,000-yr record of explosive volcanism from the GISP2 (Greenland) ice core. Quat. Res., 45(2), 109-118. 